\title{
A role of GM-CSF in the accumulation of neutrophils in the airways caused by IL-17 and TNF- $\alpha$
}

\author{
M. Laan*, O. Prause*, M. Miyamoto*, M. Sjöstrand*, A.M. Hytönen\#, T. Kaneko", J. Lötvall*, A. Lindén*
}

A role of GM-CSF in the accumulation of neutrophils in the airways caused by $I L-17$ and TNF- $\alpha$. M. Laan, O. Prause, M. Miyamoto, M. Sjöstrand, A.M. Hytönen, T. Kaneko, J. Lötvall, A. Lindén. (C) ERS Journals Ltd 2003.

ABSTRACT: The T-cell cytokine interleukin (IL)-17 selectively accumulates neutrophils in murine airways in vivo and may thus constitute a link between activation of T-lymphocytes and accumulation of neutrophils. In this study, the authors evaluated the role of granulocyte macrophage-colony stimulating factor (GM-CSF) in accumulation of neutrophils in the airways caused by IL-17 and tumour necrosis factor (TNF)- $\alpha$.

In vitro, human (h) IL-17 concentration-dependently stimulated the release of GMCSF protein (enzyme-linked immunosorbent assay) in human bronchial epithelial cells (16HBE). IL-17 also time-dependently stimulated the release of GM-CSF protein in venous endothelial (human umbilical vein endothelial cells) cells in vitro. Co-stimulation with IL-17 plus the pro-inflammatory cytokine TNF- $\alpha$ potentiated the release of GMCSF protein in 16HBE cells. hIL-17 also enhanced the expression of GM-CSF messenger ribonucleic acid in $16 \mathrm{HBE}$ cells (reverse transcriptase polymerase chain reaction), with a similar order of magnitude as TNF- $\alpha$. Conditioned cell medium from bronchial epithelial cells co-stimulated with hIL-17 plus TNF- $\alpha$ prolonged survival (trypan blue exclusion) of human neutrophils in vitro and this effect was blocked by an anti-GM-CSF antibody. In vivo, local co-stimulation with mouse IL-17 plus TNF-a caused an additive potentiation of the accumulation of neutrophils in bronchoalveolar lavage fluid from mouse airways and this effect was blocked by an anti-GM-CSF antibody given systemically.

In conclusion, granulocyte macrophage-colony stimulating factor is involved in the accumulation of neutrophils in the airways caused by interleukin-17 and tumour necrosis factor- $\alpha$, probably via effects on both recruitment and survival of neutrophils. Eur Respir J 2003; 21: 387-393.
*Lung Pharmacology Group, Dept of Respiratory Medicine and Allergology, Institute of Internal Medicine and ${ }^{\#}$ Dept of Clinical Immunology, Göteborg University, Gothenburg, Sweden. "First Dept of Internal Medicine, Yokohama City University School of Medicine, Yokohama, Japan.

Correspondence: A. Lindén, Lung Pharmacology Group, Guldhedsgatan 10A, S-413 46 Gothenburg, Sweden.

Fax: 4631413290

E-mail: anders.linden@lungall.gu.se

Keywords: Airway, cytokine, lymphocyte, neutrophil, recruitment, survival

Received: December 152001

Accepted after revision: September 19 2002

This study was supported by Herman Krefting's Foundation, the Swedish Medical Research Council (K2002-74X09048-13A), the Vardal Foundation and the Swedish Heart Lung Foundation. No support, direct or indirect, was obtained from the tobacco industry.
The accumulation of neutrophilic granulocytes occurs in several types of inflammatory airway diseases, including chronic bronchitis, chronic obstructive pulmonary disease (COPD) and acute, severe bronchial asthma [1-3]. This accumulation of neutrophils may contribute to airway obstruction, hypersecretion and remodelling by releasing proteolytic enzymes and oxygen free radicals [4-7]. Although the precise mechanisms behind this type of pathological accumulation of neutrophils are not fully understood, it seems that several cytokines controlling the production, recruitment, activation and survival of neutrophils are involved, either directly or indirectly [8-10].

Interleukin (IL)-17 is a recently characterised cytokine that is produced primarily by activated T-lymphocytes of the CD4+ and CD8+ subsets [11], cells that are involved in orchestrating various inflammatory responses $[12,13]$. The receptor for IL-17 is widely distributed and it is expressed on bronchial epithelial and endothelial cells as well as on a wide range of cells in lung tissue [14]. It is known that IL-17 can induce the production of neutrophil-mobilising cytokines, such as IL-6, IL-8 and granulocyte-colony stimulating factor, and thus has the potential to induce neutrophil recruitment indirectly [15]. IL-17 is therefore considered to be a proinflammatory cytokine. However, despite studies demonstrating increased immunoreactivity for IL-17 in the airways of patients with asthma [16] and showing increased IL-17 protein levels in human airways during severe neutrophilic inflammation [17], the pathogenetic importance of IL-17 in human airway disease remains to be confirmed.

The current authors recently demonstrated that human (h) and mouse (m) IL-17 cause a selective accumulation of neutrophils in rat airways without having any substantial effect on the accumulation of other inflammatory cell types [18]. The authors also demonstrated that hIL-17 exert its effect in the airways, in part, by releasing C-X-C chemokines [19]. This makes it feasible that IL-17 links the activation of its cellular source, the T-lymphocyte, to the accumulation of neutrophils in the airways indirectly, via induced release of neutrophil-mobilising cytokines. However, at present, it is not known whether IL-17 also causes accumulation of neutrophils in the airways by increasing the survival of neutrophils.

The cytokine granulocyte macrophage-colony stimulating factor (GM-CSF) is a growth factor that can regulate both the accumulation and the activity of neutrophils [19, 20]. GM-CSF can facilitate the recruitment of neutrophils to inflammatory sites by increasing the expression of adhesion molecules on these inflammatory cells [21] and by increasing the response of these cells to chemotactic stimuli [22]. In addition, GM-CSF can prolong the survival of neutrophils by inhibiting their apoptosis [23, 24]. In line with this, the local concentration of GM-CSF is increased in airway disease characterised by an accumulation of neutrophils [1, 25]. Factors 
that control the local release of GM-CSF may therefore indirectly modulate the accumulation of neutrophils.

The primary aim of the current study was to determine whether IL-17 per se or IL-17 with another pro-inflammmatory cytokine, tumour necrosis factor (TNF)- $\alpha$, can induce the production of GM-CSF in cells present in the airway wall and thereby modulate the survival of neutrophils. The secondary aim was to determine whether GM-CSF is involved in accumulation of neutrophils in the airways caused by IL-17 and TNF- $\alpha$.

\section{Methods}

\section{In vitro experiments}

Transformed human bronchial epithelial (16HBE14 $\left.4_{0-}(16 \mathrm{HBE})\right)$ cells [26] were kindly donated by D.C. Gruenert (Gene Therapy Center, Cardiovascular Research Institute, Dept of Laboratory Medicine, University of California, CA, USA) and were used because of their ability to respond to inflammatory stimuli in a similar manner to primary human bronchial epithelial cells [27]. As an example of venous endothelial cells, human umbilical vein endothelial cells (HUVEC; Clonetics, San Diego, CA, USA) were used [28, 29].

Cell culture conditions. 16HBE cells were grown in MEM Eagle-Eagle medium (GIBCO BRL, Life technology, Gaithesburg, MD, USA) with foetal calf serum (FCS; Sigma, St Louis, MO, USA) $(10 \%)$, L-glutamine $(2 \mathrm{mM})$, penicillin/streptomycin (100 U $\cdot \mathrm{mL}^{-1}$ and $100 \mu \mathrm{g} \cdot \mathrm{mL}^{-1}$, respectively; Sigma) and amphotericin B $\left(5 \mu \mathrm{g} \cdot \mathrm{mL}^{-1}\right.$; Sigma) on collagen (bovine, type I; BD Biosciences, Bedford, MA, USA) and fibronectin (human; BD Biosciences) coated dishes [30]. HUVEC cells were grown in endothelial cell basal medium (Clonetics), supplemented with FCS $(6 \%)$, hydrocortisone $\left(1 \mu \mathrm{g} \cdot \mathrm{mL}^{-1}\right.$; Sigma $)$, recombinant human epidermal growth factor $\left(0.01 \mu \mathrm{g} \cdot \mathrm{mL}^{-1}\right)$, gentamicin $\left(25 \mu \mathrm{g} \cdot \mathrm{mL}^{-1}\right)$, amphotericin B $\left(0.025 \mu \mathrm{g} \cdot \mathrm{mL}^{-1}\right)$ and bovine brain extract $\left(12 \mu \mathrm{g} \cdot \mathrm{mL}^{-1}\right)$. All cells were grown to confluence in six-well plastic plates (BD Biosciences). At $18 \mathrm{~h}$ prior to the experiments, the concentration of FCS was reduced to $1 \%$ in $16 \mathrm{HBE}$ and to $2 \%$ in HUVEC cells to minimise the basal (inherent) cytokine release. Before addition of the stimulus, the cells were washed twice with phosphate-buffered saline (PBS; Sigma) and placed in fresh medium with $1 \%(16 \mathrm{HBE})$ or $2 \%$ (HUVEC) FCS. PBS supplemented with $0.1 \%$ bovine serum albumin (BSA; Sigma) was used to deliver hIL-17 and hTNF- $\alpha$ and was also used as a vehicle.

Granulocyte macrophage-colony stimulating factor protein levels. Conditioned media were removed from cells and frozen at the end of each experiment. Thawed samples were centrifuged $(1,700 \times g$ for $10 \mathrm{~min})$ to pellet cells and cell debris. The supernatants were diluted and analysed using a high-sensitivity enzyme-linked immunosorbent assay (ELISA) for human GM-CSF (R\&D Systems, Abingdon, UK).

Expression of $m R N A$ for human granulocyte macrophagecolony stimulating factor. $16 \mathrm{HBE}$ cells were grown to confluence in six-well plates and treated with hIL-17, hTNF- $\alpha$, the combination of hIL-17 and hTNF- $\alpha$ or vehicle. After $6 \mathrm{~h}$ the cells were harvested by scraping, washed with PBS and then suspended in ribonucleic acid (RNA) STAT-60 (TEL-TEST "B" INC., Friedswood, TX, USA). Total RNA was isolated and analysed using reverse transcriptase polymerase chain reaction (RT-PCR), as previously described [25, 31], using simultaneous amplification of $\beta$-actin as an internal standard. Results were expressed as a ratio calculated from the volume of the amplified GM-CSF messenger (m)RNA product divided by the volume of the amplified housekeeping ( $\beta$-actin) mRNA.

Neutrophil survival. Neutrophils were isolated from peripheral blood of healthy adult volunteers. Whole blood was sedimented in the presence of $4.5 \%$ Dextran T500 solution (Amersham-Pharmacia) for $1 \mathrm{~h}$ to remove red blood cells, monocytes and lymphocytes [32]. The residual erythrocytes were lysed in distilled water containing $0.8 \% \mathrm{NH}_{4} \mathrm{Cl}$ and $0.1 \%$ $\mathrm{KHCO}_{3}$, and the remaining neutrophils were washed twice with Hanks balanced salt solution (Clonetics). Finally, the neutrophils were suspended in incubation medium (see below). This fraction contained (mean (SD)) 92\% (1.2) neutrophils $(n=4)$ with a viability of $>95 \%$. To establish the indirect effect of IL-17 and TNF- $\alpha$ on neutrophil survival, the neutrophils (final concentration $3 \times 10^{6} \cdot \mathrm{mL}^{-1}$ ) were suspended in conditioned media from $16 \mathrm{HBE}$ cells treated either with hIL-17, hTNF- $\alpha$, the combination of hIL-17 and hTNF- $\alpha$ with and without antiGM-CSF antibody, or vehicle and incubated at $37^{\circ} \mathrm{C}$ for a total of $96 \mathrm{~h}$. To establish the direct effect of IL-17 on neutrophil survival the freshly prepared neutrophils $\left(3 \times 106 \cdot \mathrm{mL}^{-1}\right)$ were incubated in nonconditioned MEM Eagle-Eagle medium with FCS $(1 \%)$, L-glutamine $(2 \mathrm{mM})$ and penicillin/streptomycin $\left(100 \mathrm{U} \cdot \mathrm{mL}^{-1}\right.$ and $100 \mu \mathrm{g} \cdot \mathrm{mL}^{-1}$, respectively) containing $100 \mathrm{ng}$. $\mathrm{mL}^{-1}$ of IL-17. PBS with $0.1 \%$ of BSA (corresponds to the BSA concentration in PBS solution used as the delivery solution for the cytokines) was used as a negative control and GM-CSF $\left(300 \mathrm{pg} \cdot \mathrm{mL}^{-1}\right)$ as a positive control. Survival of neutrophils was assessed at every 24 -h interval using trypan blue exclusion [33].

\section{In vivo experiments}

Pathogen-free C57BL/6 mice (male, 6-8 weeks old; B\&K Universal AB, Stockholm, Sweden) were used under conditions approved by the Animal Ethics Committee in Gothenburg, Sweden (DNo. 316/98).

Intranasal treatment. The mice were transiently anaesthetised using carbon dioxide ( $\mathrm{CO}_{2}$; AGA Gas AB, Gothenburg, Sweden) and $50 \mu \mathrm{l}$ of cytokine solution (dissolved in PBS solution containing $0.1 \%$ of BSA) was administered intranasally (i.n.). As a vehicle, $0.1 \%$ of BSA in PBS $(50 \mu \mathrm{l})$ was used. The concentrations of mIL-17 and mTNF- $\alpha$ were chosen based on previous experiments in which $3 \mathrm{pg}$ of $\mathrm{mIL}-17$ and $0.01 \mu \mathrm{g}$ of mTNF- $\alpha$ produced near-maximal effects in terms of neutrophil recruitment (data not shown).

Systemic blockade of granulocyte macrophage-colony stimulating factor. The mice were transiently anaesthetised using $\mathrm{CO}_{2}$ gas and a specific monoclonal anti-mGM-CSF antibody (R\&D Systems) that was administered intraperitoneally (i.p.) (100 $\mu \mathrm{g}$ in $0.1 \mathrm{~mL}$ PBS) $24 \mathrm{~h}$ prior to i.n. treatment. An isotype antibody (rat immunoglobulin (Ig)G2a; BD Biosciences) was administered i.p. (100 $\mu \mathrm{g}$ in $0.1 \mathrm{~mL}$ PBS $)$ as a control.

Bronchoalveolar lavage. The mice were anaesthetised i.p. with a mixture of xylazin $\left(130 \mathrm{mg} \cdot \mathrm{kg}^{-1}\right)$ and ketamine $\left(670 \mathrm{mg} \cdot \mathrm{kg}^{-1}\right)$ (Apoteksbolaget, Gothenburg, Sweden) $6 \mathrm{~h}$ after intranasal treatment with cytokines or vehicle. Thereafter, tracheotomy was performed and bronchoalveolar lavage (BAL) was conducted (two times $0.25 \mathrm{~mL}$ of PBS) via a tracheal cannula. The recovered BAL suspension was pooled and kept on ice until centrifugation (at $100 \times g, 10 \mathrm{~min}, 4^{\circ} \mathrm{C}$, using model 5403; Eppendorf-Netheler, Hamburg, Germany). The total number (i.e. concentration) of 
cells was determined using resuspended cell pellets from BAL suspension.

Neutrophil counts in bronchoalveolar lavage. Neutrophil counts were performed on cytospin slides prepared from BAL fluid (Cytospin 3; Shandon Life Science, Astmor, UK), using May-Grunwald-Giemsa staining. All slides were evaluated in a light microscope (Zeiss Axioplan 2; Carl Zeiss AG, Jena, Germany) at $\times 1,000$ magnification. The percentage and total number of neutrophils were calculated based on differential counts of 400 cells per sample.

\section{Statistical analysis}

Descriptive statistics are presented as median and range in text and as median plus single observations in figures. Only nonparametric methods were used for statistical analysis. Spearman rank correlation was used for correlation analysis of data. Wilcoxon's signed-rank test was used for single paired comparisons and Kruskal Wallis test followed by Mann-Whitney U-test for comparisons between multiple independent groups. The number of independent experiments for each treatment group is referred to as n.

\section{Results}

In vitro experiments

Effect of IL-17 on granulocyte macrophage-colony stimulating factor protein release. In the concentration range 1-1,000 ng$\mathrm{mL}^{-1}$, hIL-17 increased the hGM-CSF concentration in conditioned medium from $16 \mathrm{HBE}$ cells in a concentrationdependent fashion (fig. 1). Co-incubation with an anti-hIL-17 antibody blocked this increase in hGM-CSF (fig. 1), as did pretreatment with hydrocortisone (fig. 2). hIL-17 (1-1,000 ng. $\mathrm{mL}^{-1}$ ) also increased hGM-CSF in a concentration-dependent fashion in HUVEC cells ( $n=2$, data not shown).

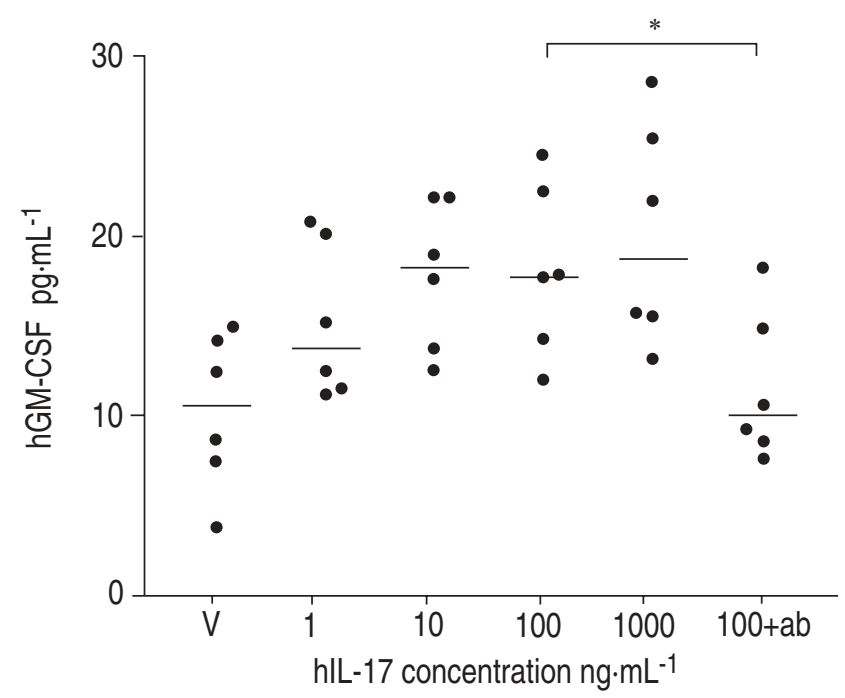

Fig. 1. - Concentration-dependent increase ( $\mathrm{r}=0.7, \mathrm{p}<0.05, \mathrm{n}=6$, compared with vehicle (V)-treated cells) of human granulocyte macrophage colony-stimulating factor (hGM-CSF) protein in conditioned medium from $16 \mathrm{HBE}$ cells after stimulation with human interleukin (hIL)-17. Co-incubation with a neutralising anti-hIL-17 antibody (ab) prior to stimulation blocked the effect of hIL-17. Data are presented as median (vertical bold line) plus individual values. *: Wilcoxon signed-rank $\mathrm{p}<0.05, \mathrm{n}=6$

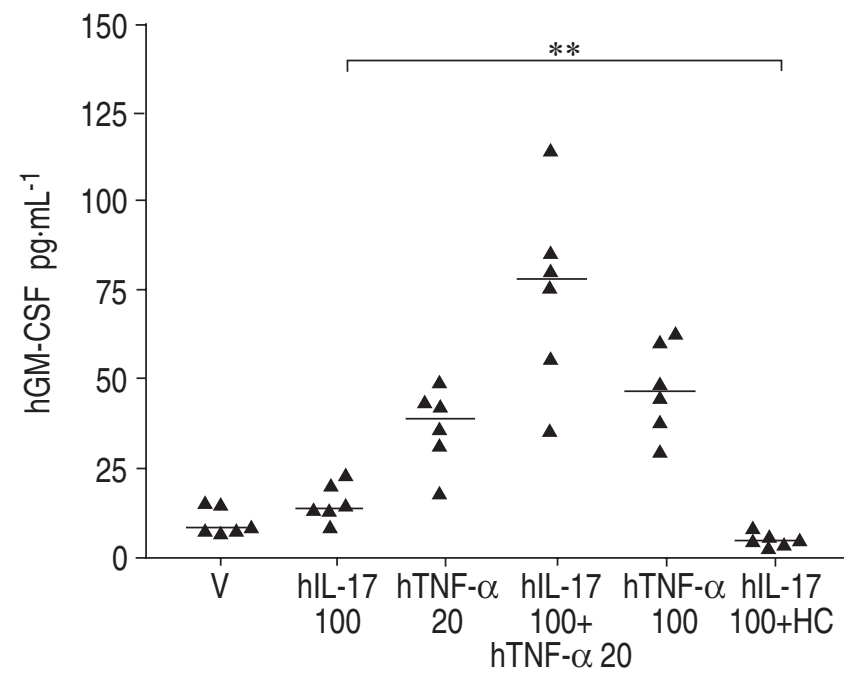

Fig. 2.-Effect of 18-h stimulation with human interleukin (hIL)-17, with and without hydrocortisone (HC) or human tumour necrosis factor (hTNF)- $\alpha\left(\mathrm{ng} \cdot \mathrm{mL}^{-1}\right)$, compared with vehicle $(\mathrm{V})$ on human granulocyte macrophage-colony stimulating factor (hGM-CSF) protein concentration in conditioned medium from 16HBE cells. Co-treatment with hIL-17 and hTNF- $\alpha$ produced a synergistic effect on the concentration of hGM-CSF (Wilcoxon signed-rank $\mathrm{p}<0.05$, compared with the sum of IL-17 alone or hTNF- $\alpha$ alone, $n=6)$. The concentration of hGM-CSF after this co-treatment was also significantly higher (Wilcoxon signed-rank $\mathrm{p}<0.05, \mathrm{n}=6$ ) than after treatment with a maximum effective concentration of hTNF- $\alpha$ alone. Pretreatment with $\mathrm{HC}$ abolished the increase in hGM-CSF protein caused by hIL17. Data are presented as median (vertical bold line) plus individual values. $^{* *}$ : Wilcoxon signed-rank $\mathrm{p}<0.01, \mathrm{n}=6$.

In the time range $2-18 \mathrm{~h}, \mathrm{hIL}-17\left(100 \mathrm{ng} \cdot \mathrm{mL}^{-1}\right)$ increased the concentration of hGM-CSF in conditioned medium from HUVEC cells in a time-dependent fashion (fig. 3). Costimulation of $16 \mathrm{HBE}$ cells with hIL-17 $\left(100 \mathrm{ng} \cdot \mathrm{mL}^{-1}\right)$ plus $\mathrm{hTNF}-\alpha\left(20 \mathrm{ng} \cdot \mathrm{mL}^{-1}\right)$ exerted a synergistic effect on the release of hGM-CSF (fig. 2). This synergistic release of hGM-CSF was more pronounced than that observed after treatment with a maximum effective concentration $\left(100 \mathrm{ng} \cdot \mathrm{mL}^{-1}\right)$ of hTNF- $\alpha$

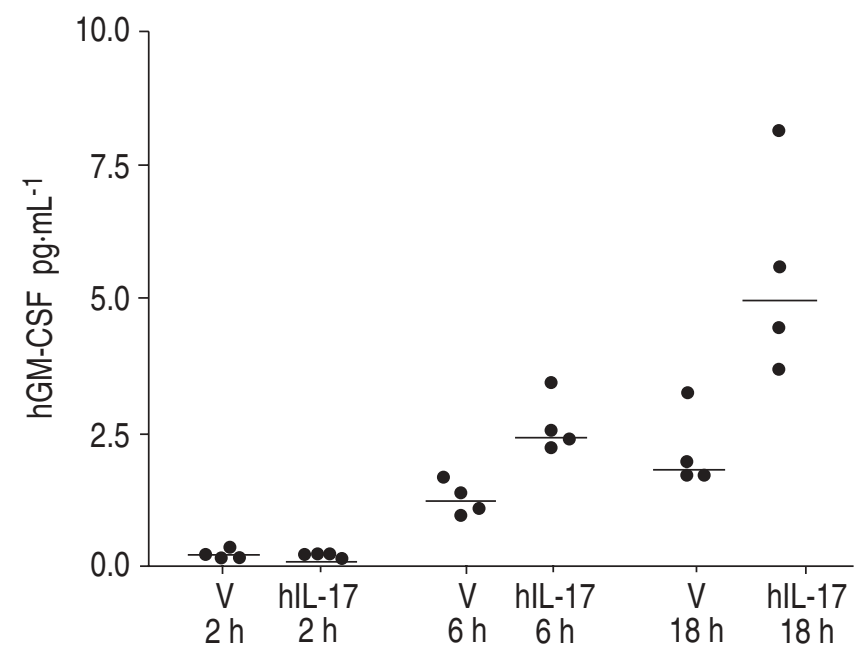

Fig. 3. - Time-dependent increase $(r=0.9, p<0.05, n=4$, compared with vehicle (V)-treated cells) of human granulocyte macrophage-colony stimulating factor (hGM-CSF) protein concentration in conditioned medium from human umbilical vein endothelial cells induced by stimulation with human interleukin (hIL)-17 $\left(100 \mathrm{ng} \cdot \mathrm{mL}^{-1}\right)$. Data are presented as median (vertical bold line) plus individual values. 


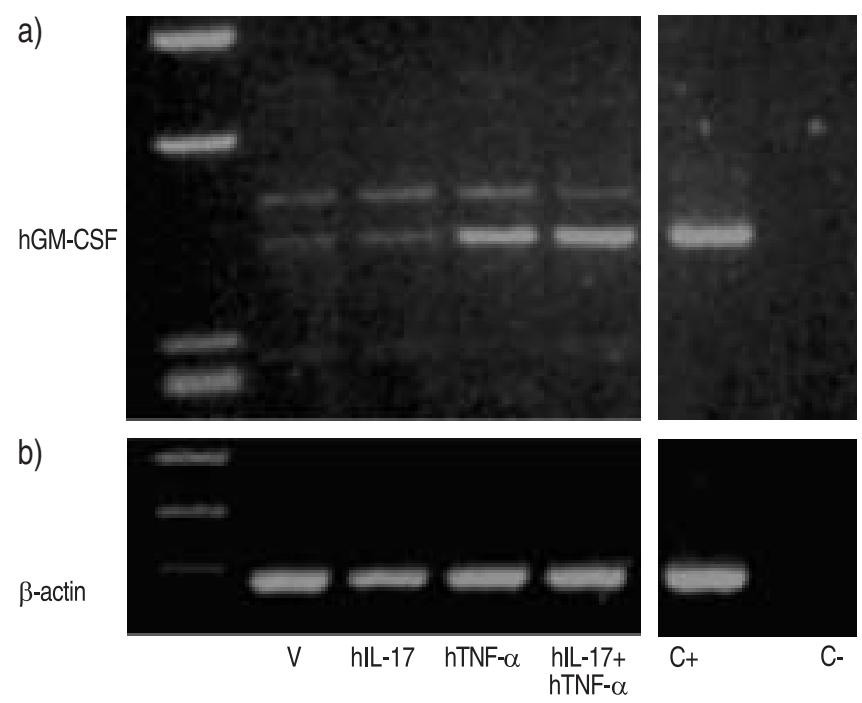

Fig. 4.-Expression of messenger ribonucleic acid for a) human granulocyte macrophage-colony stimulating factor (hGM-CSF) and b) $\beta$-actin after 6-h stimulation with either human interleukin (hIL)-17 protein $\left(100 \mathrm{ng} \cdot \mathrm{mL}^{-1}\right)$, human tumour necrosis factor (hTNF)- $\alpha$ (20 ng. $\mathrm{mL}^{-1}$ ), the combination of hIL-17 and hTNF- $\alpha$ or vehicle (V) only, in $16 \mathrm{HBE}$ cells in a gel from one representative sample. C: control.

alone (fig. 2). hIL-17 (100 $\left.\mathrm{ng} \cdot \mathrm{mL}^{-1}\right)$ also increased hGM-CSF in a time-dependent fashion in $16 \mathrm{HBE}$ cells $(n=2$, data not shown).

Effect of IL-17 on granulocyte macrophage-colony stimulating factor $m R N A$ levels. Stimulation of a 6-h duration of $16 \mathrm{HBE}$ cells with hIL-17 $\left(100 \mathrm{ng} \cdot \mathrm{mL}^{-1}\right)$ increased the hGM-CSF/ $\beta$-actin mRNA ratio (figs. 4 and 5). The magnitude of this effect was comparable to that of TNF- $\alpha\left(20 \mathrm{ng} \cdot \mathrm{mL}^{-1}\right)$, whereas the combination of hIL-17 plus hTNF- $\alpha$ (100 and $20 \mathrm{ng} \cdot \mathrm{mL}^{-1}$, respectively) did not produce any additive effect on hGM-CSF/ $\beta$-actin mRNA ratio (figs. 4 and 5).

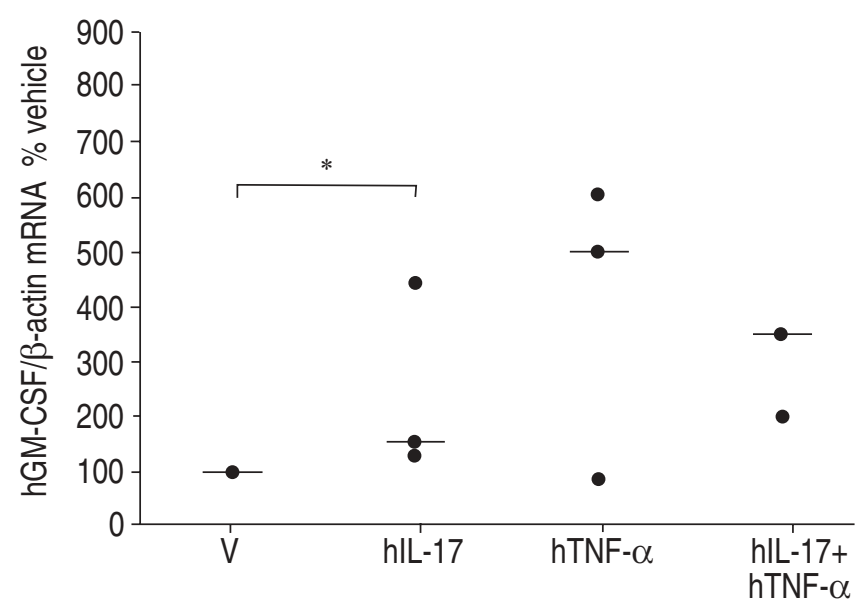

Fig. 5.-Expression of messenger ribonucleic acid (mRNA) for human granulocyte macrophage-colony stimulating factor (hGMCSF) and $\beta$-actin after 6-h stimulation with either human interleukin (hIL)-17 protein, human tumour necrosis factor (hTNF)- $\alpha$, the combination of hIL-17 and hTNF- $\alpha$ or vehicle (V) only in $16 \mathrm{HBE}$ cells. The GM-CSF/ $\beta$-actin mRNA ratio, as measured by photodensitometry, is presented as \% of ratio in V-treated cells (measured median (range) for $\mathrm{V}$ was $0.16(0.07-0.87)$ ). Data are presented as median (vertical bold line) plus individual values. *: Mann-Whitney U-test $\mathrm{p}<0.05, \mathrm{n}=3$.
Indirect effect of interleukin-17 on neutrophil survival. The indirect effect of IL-17 was evaluated by exposing human neutrophils to cell culture medium from human bronchial epithelial cells $(16 \mathrm{HBE}$ cells) that had been stimulated $(18 \mathrm{~h})$ with hIL-17 (100 ng. $\left.\mathrm{mL}^{-1}\right)$, hTNF- $\alpha\left(20 \mathrm{ng} \cdot \mathrm{mL}^{-1}\right)$, the combination of hIL-17 $\left(100 \mathrm{ng} \cdot \mathrm{mL}^{-1}\right)$ plus hTNF- $\alpha\left(20 \mathrm{ng} \cdot \mathrm{mL}^{-1}\right)$ or vehicle. The survival of neutrophils was evaluated every $24 \mathrm{~h}$ by calculating the area under the curve (AUC; number of living neutrophils $\times \mathrm{h}$ ) over $48-96 \mathrm{~h}$ and the differences were also compared at every single time point, which were most pronounced at $72 \mathrm{~h}$ (fig. 6). Over 48-96 h, conditioned medium from $16 \mathrm{HBE}$ cells co-stimulated with hIL-17 plus hTNF- $\alpha$ prolonged the survival of human neutrophils (AUC 2,299.6 $(1,774.0-2,433.6))$, compared with neutrophils exposed to conditioned cell medium from $16 \mathrm{HBE}$ cells stimulated with hTNF- $\alpha$ alone (AUC 1,765.6 (1,505.5-2,322.0) $(\mathrm{p}<0.05, \mathrm{n}=6)$. Pretreatment of this conditioned medium with a neutralising anti-hGM-CSF antibody $\left(10 \mathrm{pg} \cdot \mathrm{mL}^{-1}\right.$ added simultaneously with cytokines) blocked the prolonging effect on neutrophil survival (AUC 1,527.7 (1,433.9-1,922.2)) $(\mathrm{p}<0.05, \mathrm{n}=6)$. However, as was also shown at $72 \mathrm{~h}$ (fig. 6), neither conditioned medium from $16 \mathrm{HBE}$ cells co-stimulated with hIL-17 plus hTNF- $\alpha$ nor the one stimulated with either hIL-17 alone (AUC $1,855.0(1,611.0-2,581.6))$ or hTNF- $\alpha$ alone (AUC 1,765.6 $(1,505.5-2,322.0))$ prolonged neutrophil survival significantly compared with conditioned medium from vehicle-stimulated 16HBE cells (AUC 1,720.5 (1,594.9-2,133.7)) $(\mathrm{p}>0.05, \mathrm{n}=6)$.

Direct effect of interleukin-17 on neutrophil survival. Stimulation of neutrophils in the time range $48-96 \mathrm{~h}$ with either hIL-17 (100 ng.mL ${ }^{-1}$; AUC 1,004.2 (853.2-1,373.5)), hTNF- $\alpha\left(20 \mathrm{ng} \cdot \mathrm{mL}^{-1}\right.$; AUC $\left.974.3(523.2-1,376.3)\right)$ or the combination of hIL-17 plus TNF- $\alpha\left(100 \mathrm{ng} \cdot \mathrm{mL}^{-1}\right.$ and $20 \mathrm{ng} \cdot \mathrm{mL}^{-1}$, respectively; AUC 1,216.4 (978.8-1,590.5)) displayed no

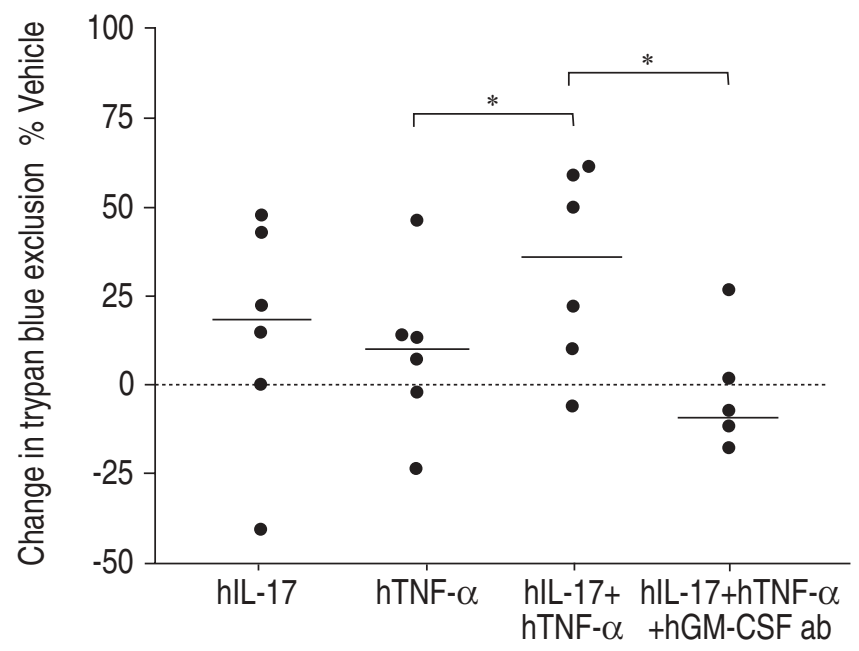

Fig. 6. - Indirect effect of human interleukin (hIL)-17 and human tumour necrosis factor (hTNF)- $\alpha$ on the survival of human neutrophils in vitro as determined by exclusion of trypan blue dye. Neutrophil survival was compared at $72 \mathrm{~h}$ after exposure to conditioned medium from 16HBE cells stimulated with vehicle (V). Conditioned media from 16HBE cells stimulated with either hIL-17 (100 ng $\left.\cdot \mathrm{mL}^{-1}\right)$, hTNF- $\alpha\left(20 \mathrm{ng} \cdot \mathrm{mL}^{-1}\right)$, the combination of hIL-17 plus hTNF- $\alpha$ or the combination of hIL-17 plus hTNF- $\alpha$ plus a neutralising antihuman granulocyte macrophage-colony stimulating factor (hGM-CSF) antibody (ab) were tested. hIL-17+hTNF- $\alpha$ medium displayed a significantly higher neutrophil survival than hTNF- $\alpha$ medium and hIL-17+hTNF- $\alpha+$ GM-CSF ab medium, respectively. Data are presented as median (vertical bold line) plus individual values. *: Wilcoxon signed-rank $\mathrm{p}<0.05, \mathrm{n}=6$. 
substantial direct effect on neutrophil survival as compared with vehicle (AUC 1,254.4 (868.1-1,284.7)) $(\mathrm{p}>0.05, \mathrm{n}=3)$.

\section{In vivo experiments}

Effect on neutrophil recruitment in vivo. i.n. stimulation with mIL-17 markedly increased the number of neutrophils in BAL fluid and this accumulation of neutrophils was additively potentiated by mTNF- $\alpha$ (fig. 7a). Pretreatment with the antimGM-CSF antibody i.p. abolished the increase in BAL neutrophils caused by stimulation with IL-17 plus TNF- $\alpha$ i.n. (fig. 7b).

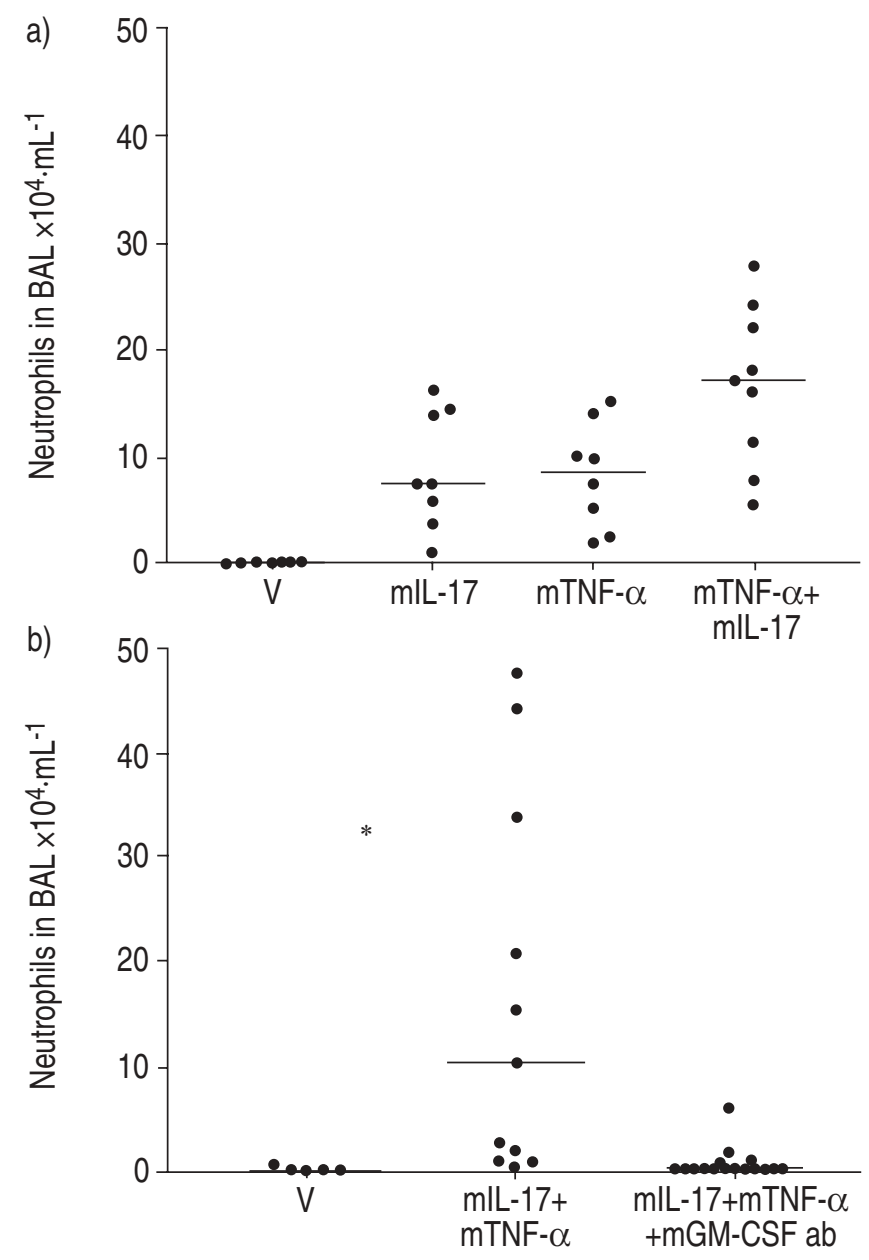

Fig. 7.-Effect of local (intranasal (i.n.)) stimulation with mouse interleukin (mIL)-17 $\mu \mathrm{g}$ and mouse tumour necrosis factor (mTNF)- $\alpha$ $(0.01 \mu \mathrm{g})$ compared with vehicle $(\mathrm{V})$ on the accumulation of neutrophils in bronchoalveolar lavage (BAL) fluid harvested from mice in vivo. a) Stimulation i.n. with mIL-17 and with mTNF- $\alpha$ significantly increased the number of neutrophils in BAL fluid (Kruskal-Wallis $\mathrm{p}<0.0005, \mathrm{n}=6-9$, Mann-Whitney U-test $\mathrm{p}<0.005$ for mIL-17 compared with V; Mann-Whitney U-test $\mathrm{p}<0.005$ for $\mathrm{mTNF}-\alpha$ compared with $\mathrm{V}$ ) in mice and co-stimulation with mIL-17 and mTNF- $\alpha$ i.n. increased the accumulation of neutrophils in BAL fluid even more (Mann-Whitney U-test $\mathrm{p}<0.05$ compared with mIL-17 alone and $\mathrm{p}<0.05$ compared with $\mathrm{mTNF}-\alpha$ alone). b) The effect of systemic (intraperitonial) pretreatment $(24 \mathrm{~h}$ prior to cytokines i.n.) with a neutralising antimouse granulocyte macrophage-colony stimulating factor (mGM-CSF) antibody (ab) on neutrophil accumulation caused by local (i.n.) co-stimulation with mIL-17 plus mTNF- $\alpha$ (KruskalWallis $\mathrm{p}<0.001$, Mann-Whitney U-test $\mathrm{p}<0.001, \mathrm{n}=5-12)$. Data are presented as median (vertical bold line) plus individual values.

\section{Discussion}

There is clear experimental in vivo evidence supporting a role for activated T-lymphocytes in the accumulation of neutrophils in the airways $[34,35]$. There is also evidence that IL-17 may constitute a mechanistic link between T-lymphocytes and neutrophils; IL-17 is produced by T-lymphocytes [18] and causes selective accumulation of neutrophils but not other inflammatory cells in the airways [25]. The current study provides additional evidence supporting the hypothesis that IL-17 constitutes a link between T-lymphocytes and neutrophils by demonstrating that IL-17, with and without costimulation with TNF- $\alpha$, causes accumulation of neutrophils depending upon GM-CSF in the airways.

Specifically, the current authors have shown that hIL-17 stimulates release of GM-CSF protein in models of human bronchial epithelial and venous endothelial cells in vitro, two potential effector cells in the local control of neutrophil recruitment in the airways. This IL-17-induced GM-CSF release appears to be both concentration- and time-dependent in the models of human bronchial epithelial and venous endothelial cells used. Furthermore, the effect of hIL-17 is probably protein specific, because it is attenuated by a neutralising antihIL-17 antibody in human bronchial epithelial cells. Previous data on receptor binding in fibroblasts suggests a low-affinity IL-17 receptor in other types of human cells [36] and the moderate effect of hIL-17 on GM-CSF release now observed in human bronchial epithelial cells, as well as the corresponding shallow concentration/response curve, also suggests a lowaffinity receptor in these cells. In line with these findings, stimulation of human bronchial epithelial cells with hIL-17 alone increases mRNA for GM-CSF with the same order of magnitude as TNF- $\alpha$, suggesting an induced de novo synthesis of GM-CSF. The inhibitory effect exerted by the glucocorticoid hydrocortisone on hIL-17-induced GM-CSF release is probably due to inhibition of the transcription factor nuclear factor (NF)- $\kappa \mathrm{B}$ [37], a factor that is known to be important in IL-17-induced cytokine release [21, 38].

Interestingly, the present authors demonstrate that costimulation with hIL-17 and hTNF- $\alpha$ potentiates the release of GM-CSF protein in human bronchial epithelial cells in vitro. They also demonstrate that this production of GM-CSF is functionally significant; conditioned medium from human bronchial epithelial cells co-stimulated with hIL-17 plus hTNF- $\alpha$ prolongs the survival of human neutrophils in vitro and this prolonging effect on survival is inhibited by a neutralising anti-hGM-CSF antibody. Finally, the authors demonstrate that hIL-17 per se exerts no direct effect on the survival of human neutrophils in vitro, thereby suggesting an indirect effect exerted by IL-17 on the accumulation of neutrophils.

The current authors show that mIL-17 potentiates mTNF$\alpha$-induced accumulation of neutrophils in mouse airways, thereby providing functional evidence for the relevance of IL-17 in vivo. In addition, the authors provide evidence that this functionally significant effect of mIL-17 and mTNF- $\alpha$ is dependent upon mGM-CSF. It appears likely that the referred GM-CSF exerts its role by increasing the recruitment of neutrophils into the airways; this latter type of effect is likely to rely on an increased release of new neutrophils from the bone marrow [12], as well as on an increased adhesion to and migration through the vascular walls in airway tissue [19-22]. The main reason for this conclusion is that the antimGM-CSF antibody was administered $24 \mathrm{~h}$ prior to intranasal stimulation with mIL-17 and mTNF- $\alpha$, and BAL was harvested $6 \mathrm{~h}$ later, giving a total maximum of $30 \mathrm{~h}$ for the antibody to act. This limited time frame makes it less likely that the in vivo effect of the anti-mGM-CSF antibody was due to an altered neutrophil survival, which would require several 
days of treatment with an anti-mGM-CSF antibody to be demonstrated. However, the mechanistic details of these events remain to be clarified through studies of bone marrow, blood and BAL fluid over time.

The current authors believe that the demonstrated potentiating effect of IL-17 and TNF- $\alpha$ on the accumulation of neutrophils in the airways has implications for human disease. Increased levels of TNF- $\alpha$ can be detected in several types of inflammatory airway diseases, including bronchial asthma and COPD $[39,40]$. As demonstrated in vitro, TNF- $\alpha$ can induce neutrophil recruitment by increasing the release of IL-6, IL-8 and GM-CSF [41]. In view of recent evidence that IL-17 itself may be present in human airways during severe inflammation [16, 17], it is possible that IL-17 interacts with $\mathrm{TNF}-\alpha$ and, through induced GM-CSF release, contributes to the accumulation of neutrophils.

In conclusion, this experimental study indicates that glucocorticoid-sensitive de novo production of granulocyte macrophage-colony stimulating factor from bronchial epithelial cells is involved in the accumulation of neutrophils in the airways caused by interleukin-17 and tumour necrosis factor$\alpha$. In addition, venous endothelial cells may also respond to interleukin-17 by releasing granulocyte macrophage-colony stimulating factor. It appears feasible that this granulocyte macrophage-colony stimulating factor exerts its functionally significant effects in vivo on both the recruitment and survival of neutrophils in the airways.

Acknowledgements. The technical assistance of M. Hahn-Zoric is gratefully acknowledged.

\section{References}

1. Balbi B, Bason C, Balleari E, et al. Increased bronchoalveolar granulocytes and granulocyte/macrophage colonystimulating factor during exacerbations of chronic bronchitis. Eur Respir J 1997; 10: 846-850.

2. Fahy JV, Kim KW, Liu J, Boushey HA. Prominent neutrophilic inflammation in sputum from subjects with asthma exacerbation. J Allergy Clin Immunol 1995; 95: 843852.

3. Lamblin C, Gosset P, Tillie-Leblond I, et al. Bronchial neutrophilia in patients with noninfectious status asthmaticus. Am J Respir Crit Care Med 1998; 15: 394402.

4. Venaille TJ, Mendis AH, Phillips MJ, Thompson PJ, Robinson BW. Role of neutrophils in mediating human epithelial cell detachment from native basement membrane. J Allergy Clin Immunol 1995; 95: 597-606.

5. Meyer KC, Zimmerman J. Neutrophil mediators, Pseudomonas, and pulmonary dysfunction in cystic fibrosis. $J \mathrm{Lab}$ Clin Med 1993; 121: 654-661.

6. Schuster A, Ueki I, Nadel JA. Neutrophil elastase stimulates tracheal submucosal gland secretion that is inhibited by ICI 200,355. Am J Physiol 1992; 262: L86-L91.

7. Weinberg KS, Hayes JA. Elastase-induced emphysema: asynchronous bronchial, alveolar and endothelial cell proliferation during the acute response to injury. J Pathol 1982; 136: 253-264.

8. Stockley RA. Role of inflammation in respiratory tract infections. Am J Med 1995; 99: 8S-13S.

9. Maestrelli P, Saetta M, Mapp CE, Fabbri LM. Remodeling in response to infection and injury. Airway inflammation and hypersecretion of mucus in smoking subjects with chronic obstructive pulmonary disease. Am J Respir Crit Care Med 2001; 164: S76-S80.

10. Wagner JG, Roth RA. Neutrophil migration mechanisms, with an emphasis on the pulmonary vasculature. Pharmacol Rev 2000; 52: 349-374.
11. Yao Z, Painter SL, Fanslow WC, et al. Human IL-17: a novel cytokine derived from T cells. J Immunol 1995; 155: 5483-5486.

12. Sinigaglia F, D'Ambrosio D. Regulation of helper $\mathrm{T}$ cell differentiation and recruitment in airway inflammation. $\mathrm{Am}$ J Respir Crit Care Med 2000; 162: S157-S160.

13. Jiang $\mathrm{H}$, Chess $\mathrm{L}$. The specific regulation of immune responses by CD8+ T cells restricted by the MHC class $\mathrm{Ib}$ molecule, Qa-1. Ann Rev Immunol 2000; 18: 185-216.

14. Yao Z, Fanslow WC, Seldin MF, et al. Herpes virus Saimiri encodes a new cytokine, IL-17, which binds to a novel cytokine receptor. Immunity 1995; 3: 811-821.

15. Fossiez F, Djossou O, Chomarat $\mathrm{P}$, et al. $\mathrm{T}$ cell interleukin17 induces stromal cells to produce proinflammatory and hematopoietic cytokines. J Exp Med 1996; 183: 25932603.

16. Molet S, Hamid Q, Davoine F, et al. IL-17 is increased in asthmatic airways and induces human bronchial fibroblasts to produce cytokines. J Allergy Clin Immunol 2001; 108: 430438.

17. Laan M, Palmberg L, Larsson K, Lindén A. Free, soluble interleukin-17 protein during severe inflammation in human airways. Eur Respir J 2002; 19: 534-537.

18. Laan M, Cui ZH, Hoshino $\mathrm{H}$, et al. Neutrophil recruitment by human IL-17 via C-X-C chemokine release in the airways. J Immunol 1999; 162: 2347-2352.

19. Fossati G, Mazzucchelli I, Gritti D, et al. In vitro effects of GM-CSF on mature peripheral blood neutrophils. Int $J \mathrm{Mol}$ Med 1998; 1: 943-951.

20. Baldwin GC. The biology of granulocyte-macrophage colony-stimulating factor: effects on hematopoietic and nonhematopoietic cells. Dev Biol 1992; 151: 352-367.

21. Yong KL, Linch DC. Differential effects of granulocyte- and granulocyte-macrophage colony- stimulating factors (G- and GM-CSF) on neutrophil adhesion in vitro and in vivo. Eur J Haematol 1992; 49: 251-259.

22. Weisbart RH, Golde DW, Clark SC, Wong GG, Gasson JC. Human granulocyte-macrophage colony-stimulating factor is a neutrophil activator. Nature 1985; 314: 361-363.

23. Brach MA, deVos S, Gruss HJ, Herrmann F. Prolongation of survival of human polymorphonuclear neutrophils by granulocyte-macrophage colony-stimulating factor is caused by inhibition of programmed cell death. Blood 1992; 80: 2920-2924.

24. Cox G, Gauldie J, Jordana M. Bronchial epithelial cellderived cytokines (G-CSF and GM-CSF) promote the survival of peripheral blood neutrophils in vitro. Am J Respir Cell Mol Biol 1992; 7: 507-513.

25. Mattoli S, Mattoso VL, Soloperto M, Allegra L, Fasoli A. Cellular and biochemical characteristics of bronchoalveolar lavage fluid in symptomatic nonallergic asthma. J Allergy Clin Immunol 1991; 87: 794-802.

26. Cozens AL, Yezzi MJ, Kunzelmann K, et al. CFTR expression and chloride secretion in polarized immortal human bronchial epithelial cells. Am J Respir Cell Mol Biol 1994; 10: 38-47.

27. Massion PP, Inoue $\mathrm{H}$, Richman-Eisenstat $\mathbf{J}$, et al. Novel Pseudomonas product stimulates interleukin-8 production in airway epithelial cells in vitro. J Clin Invest 1994; 93: 26-32.

28. Gimbrone MA Jr. Culture of vascular endothelium. Prog Hemost Thromb 1976; 3: 1-28.

29. Rot A, Hub E, Middleton J, et al. Some aspects of IL-8 pathophysiology. III: Chemokine interaction with endothelial cells. J Leukoc Biol 1996; 59: 39-44.

30. Gruenert DC, Basbaum CB, Widdicombe JH. Long-term culture of normal and cystic fibrosis epithelial cells grown under serum-free conditions. In Vitro Cell Dev Biol 1990; 26: 411-418.

31. Hagberg H, Gilland E, Bona E, et al. Enhanced expression of interleukin (IL)-1 and IL-6 messenger RNA and bioactive protein after hypoxia-ischemia in neonatal rats. Pediatr Res 1996; 40: 603-609. 
32. Von Essen SG, O'Neill DP, McGranaghan S, Olenchock SA, Rennard SI. Neutrophilic respiratory tract inflammation and peripheral blood neutrophilia after grain sorghum dust extract challenge. Chest 1995; 108: 1425-1433.

33. Lee A, Whyte MK, Haslett C. Inhibition of apoptosis and prolongation of neutrophil functional longevity by inflammatory mediators. J Leukoc Biol 1993; 54: 283-288.

34. Gavett SH, Chen X, Finkelman F, Wills-Karp M. Depletion of murine $\mathrm{CD} 4+\mathrm{T}$ lymphocytes prevents antigen-induced airway hyperreactivity and pulmonary eosinophilia. $\mathrm{Am} J$ Respir Cell Mol Biol 1994; 10: 587-593.

35. Renzi PM, Yang JP, Diamantstein T, Martin JG. Effects of depletion of cells bearing the interleukin-2 receptor on immunoglobulin production and allergic airway responses in the rat. Am J Respir Crit Care Med 1996; 153: 1214-1221.

36. Yao Z, Spriggs MK, Derry JM, et al. Molecular characterization of the human interleukin (IL)-17 receptor. Cytokine 1997; 9: 794-800.
37. Brattsand R, Linden M. Cytokine modulation by glucocorticoids: mechanisms and actions in cellular studies. Aliment Pharmacol Ther 1996; 10: Suppl 2. 81-90, discussion 91-92.

38. Shalom-Barak T, Quach J, Lotz M. Interleukin-17-induced gene expression in articular chondrocytes is associated with activation of mitogen-activated protein kinases and NF- $\mathrm{KB}$. J Biol Chem 1998; 273: 27467-27473.

39. Rink L, Kirchner H. Recent progress in the tumor necrosis factor-alpha field. Int Arch Allergy Immunol 1996; 111: 199-209.

40. Aaron SD, Angel JB, Lunau M, et al. Granulocyte inflammatory markers and airway infection during acute exacerbation of chronic obstructive pulmonary disease. $\mathrm{Am}$ J Respir Crit Care Med 2001; 163: 349-355.

41. Bedard M, McClure CD, Schiller NL, Francoeur C, Cantin A, Denis M. Release of interleukin-8, interleukin-6, and colony-stimulating factors by upper airway epithelial cells: implications for cystic fibrosis. Am J Respir Cell Mol Biol 1993; 9: 455-462. 